\title{
Role of Dipeptidyl Peptidase-4 in Atherosclerotic Cardiovascular Disease in Humans and Animals with Chronic Stress
}

\author{
Limei Piao, ${ }^{1} \mathrm{MD}$, Yanglong $\mathrm{Li},{ }^{1} \mathrm{MD}$, Megumi Narisawa, ${ }^{2} \mathrm{MD}$, \\ Xionghu Shen, ${ }^{3} \mathrm{MD}$ and Xian Wu Cheng, ${ }^{1} \mathrm{MD}$
}

\begin{abstract}
Summary
Exposure to psychosocial stress is a risk factor for cardiovascular disease, including vascular atherosclerosis-based cardiovascular disease (ACVD). Dipeptidyl peptidase-4 (DPP-4) is a complex enzyme that acts as a membrane-anchored cell surface exopeptidase. DPP-4 is upregulated in metabolic and inflammatory cardiovascular disorders. DPP-4 exhibits many physiological and pharmacological functions by regulating its extremely abundant substrates, such as glucagon-like peptide-1 (GLP-1). Over the last 10 years, emerging data have demonstrated unexpected roles of DPP-4 in extracellular and intracellular signaling, immune activation, inflammation, oxidative stress production, cell apoptosis, insulin resistance, and lipid metabolism. This minireview focuses on recent novel findings in this field, highlighting a DPP-4-mediated regulation of GLP-1dependent and -independent signaling pathways as a potential therapeutic molecular target in treatments of chronic psychological stress-related ACVD in humans and animals.
\end{abstract}

Key words: Vascular senescence, Atherosclerosis, Inflammation, Oxidative stress

(Int Heart J 2021; 62: 470-478)

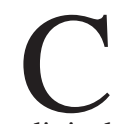
hronic psychological stress (CPS) is considered a risk factor for vascular aging and atherosclerosisbased cardiovascular disease (ACVD), based on clinical and experimental observations (Table). ${ }^{1)}$ The importance of various psychological stressors as contributors to the initiation and progression of vascular senescence and ACVD has been the focus of concerted research efforts over the past several decades. ${ }^{2-5)}$ For example, the large-scale case-control INTERHEART trial conducted in 51 countries demonstrated that chronic psychological stressors (e.g., depression, perceived life stress, major life events, and low sense of control) pose an adjusted 2.7fold enhanced risk of acute myocardial infarction (AMI). ${ }^{6}$ Indeed, the contribution of psychological factors (e.g., anxiety and depression) to the increased likelihood of recurrent coronary arterial events after coronary artery bypass grafting and AMI is known, and it is well documented that transient psychological stress may cause potentially fatal arrhythmias and acute cardiovascular events. ${ }^{7}$ Over the last 10 years, it has been established that chronic psychological stressors in modern lifestyles are associated closely with the incidence of hypertension, metabolic syndrome, diabetes mellitus (DM), and cardiovascular diseases (CVDs). ${ }^{8)}$ Clinical and laboratory findings from our team and other groups showed that chronic psychological stressors activate intra- and extracellular pathways (including the hypothalamic-pituitary-adrenal axis and the sympathetic nervous system) by eliciting pathophysiological overactions, resulting in metabolic and inflammatory cardiovascular disorders (Table). ${ }^{9-12)}$ However, the precise mechanisms involved in stress-related vascular aging and atherosclerotic lesion formation and progression remain largely uncertain.

\section{A Brief Review of DPP-4}

The biological and molecular functions of DPP-4: The human gene encoding dipeptidyl peptidase-4 (DPP-4) has been reported to localize to chromosome 2 locus $2 \mathrm{q} 24.2 .^{13)}$ DPP-4 is a member of a complex gene family, several members of which nonspecifically truncate many structure-related peptides, including cytokines, chemokines, neuropeptides, hormones, and growth factors. ${ }^{14)}$ Figure 1 shows the gene family of DPP-4-related proteases and their expression of cell types, substrate specificities, working spaces, and functions. The DPP-4 protease family includes $N$-acetylated- $\alpha$-linked acidic dipeptidase I, II, L, seprase, DPP-1v $\beta$, DPP-6, DPP-8, DPP-9, fibroblast activation protein $\alpha$, folate hydrolase, prostate-specific membrane antigen, pteroylpoly- $\gamma$-glutamate carboxypeptidase,

From the ${ }^{1}$ Department of Cardiology, Yanbian University Hospital, Yanji, China, ${ }^{2}$ Department of Cardiology, Nagoya University Graduate School of Medicine, Nagoya, Japan and ${ }^{3}$ Department of Oncology, Yanbian University Hospital, Yanji, China.

This work was supported in part by the Scientific Research Fund of the Chinese Ministry of Education (nos. 81560240 and 81770485 ).

Address for correspondence: Xian Wu Cheng, MD, Department of Cardiology, Yanbian University Hospital, 1327 Juzijie, Yanji, Jilin, 133000 China. E-mail: xianwu@med.nagoya-u.ac.jp, chengxw0908@163.com or Xionghu Shen, MD, Department of Oncology, Yanbian University Hospital, 1327 Juzijie, Yanji, Jilin, 133000 China. E-mail: ghsxwc0908@yahoo.co.jp

Received for publication March 23, 2020. Revised and accepted November 19, 2020.

Released in advance online on J-STAGE May 15, 2021.

doi: 10.1536/ihj.20-181

All rights reserved by the International Heart Journal Association. 
Table. Experimental Studies of Chronic Stressors on Vascular Aging, Angiogenesis, and Atherosclerosis

\begin{tabular}{|c|c|c|c|c|c|c|}
\hline $\begin{array}{l}\text { Diseases and } \\
\text { implications }\end{array}$ & $\begin{array}{c}\text { Animals } \\
\text { Publication } \\
\text { year/journal }\end{array}$ & Stressor & Treatment & Mechanism & $\begin{array}{l}\text { Morphological and } \\
\text { functional alterations }\end{array}$ & Ref. \\
\hline Angiogenesis & $\begin{array}{c}\text { BALB/c } \\
\text { (2015) } \\
\text { Atherosclerosis }\end{array}$ & $\begin{array}{c}\text { Immobilized } \\
\text { stress } \\
\text { (3 weeks) }\end{array}$ & $\begin{array}{c}\text { Fluoxetine } \\
\text { hydrochloride } \\
\text { (18 mg/kg/day) }\end{array}$ & $\begin{array}{c}\text { Oxidative stress } \downarrow / \\
\text { VEGF } \uparrow / \\
\text { p-Erk } 1 / 2 \uparrow\end{array}$ & $\begin{array}{c}\text { Blood flow } \uparrow \\
\text { Capillary density } \uparrow\end{array}$ & 5 \\
\hline $\begin{array}{l}\text { Metabolic } \\
\text { disorder } \\
\text { Prothrombosis }\end{array}$ & $\begin{array}{l}\text { C57BL/6j } \\
(2012) \\
\text { Diabetes }\end{array}$ & $\begin{array}{c}\text { Immobilized } \\
\text { stress } \\
(2 \text { weeks })\end{array}$ & $\begin{array}{l}\text { 7ND } \\
\text { Human MCP-1 neu- } \\
\text { tralizing antibody }\end{array}$ & $\begin{array}{c}\text { Inflammation } \downarrow \\
\text { GTT (-) /ITT } \downarrow \\
\text { PAI-1/TF } \downarrow \\
\text { MCP-1 } \downarrow \\
\text { TNF- } \alpha / \text { IL-6 } \downarrow\end{array}$ & $\begin{array}{c}\text { Macrophage infiltration } \downarrow \\
\text { Insulin resistance } \downarrow \\
\text { Prothrombosis } \downarrow\end{array}$ & 21 \\
\hline $\begin{array}{l}\text { HSC } \\
\text { activation } \\
\text { Atherosclerosis }\end{array}$ & $\begin{array}{c}\text { C57BL/6J, } \\
\text { ApoE }^{-/-} \\
(\mathrm{B} 6.129 \mathrm{P} 2- \\
\text { Apoetm1Unc/J), } \\
(2014) \\
\text { Nature } \\
\text { Medicine }\end{array}$ & $\begin{array}{l}\text { Chronic } \\
\text { variable } \\
\text { stress } \\
\text { (6 weeks) }\end{array}$ & & $\begin{array}{c}\text { Bone marrow niche } \\
\text { Adr } \beta 3 \uparrow / C X C L 12 \downarrow \\
\text { Plasma adrenaline/ } \\
\text { Noradrenaline } \uparrow\end{array}$ & $\begin{array}{c}\text { Bone marrow } \\
\text { lin- }^{-} \text {-Kit }{ }^{\text {high }} \text { Sca- } 1^{\text {high }} \\
\text { CD } 48^{\text {low }} \text { CD } 150^{\text {high }} \\
\text { HSCs } \downarrow \\
\text { Peripheral blood neutro- } \\
\text { phils } \downarrow \\
\text { Monocytes } \downarrow \\
\text { Leukocytes } \downarrow \\
\text { Atherosclerotic plaque } \uparrow\end{array}$ & 25 \\
\hline $\begin{array}{l}\text { HSC } \\
\text { activation }\end{array}$ & $\begin{array}{c}\text { C57BL/6j } \\
\text { DPP4 }{ }^{-/-} \text {rats } \\
(2017) \\
\text { Journal of } \\
\text { American Heart } \\
\text { Association }\end{array}$ & $\begin{array}{c}\text { Immobilized } \\
\text { stress } \\
\text { (2 weeks) }\end{array}$ & $\begin{array}{c}\text { Anagliptin } \\
(30 \mathrm{mg} / \mathrm{kg} / \mathrm{day}) \\
\text { Exenatide } \\
(5 \mu \mathrm{g} / \mathrm{kg} / \mathrm{day}) \\
\text { A specific Adr } 33 \\
\text { inhibitor }(\mathrm{L} 748337 \text { : } \\
0.5 \mathrm{mg} / \mathrm{kg} / \text { day })\end{array}$ & $\begin{array}{c}\text { Brain GLP-1R } \uparrow \\
\text { Bone marrow niche } \\
\text { Adr } \beta 3 \downarrow / \mathrm{CXCL} 12 \uparrow \\
\text { Plasma adrenaline/ } \\
\text { Noradrenaline } \downarrow \\
\text { MMP-2/MMP-9 } \downarrow \\
\text { Plasma DPP4 } \downarrow / \mathrm{APN} \uparrow\end{array}$ & $\begin{array}{c}\text { Bone marrow } \\
\text { lin }^{-} \text {c-Kit } \\
\text { CD } 48^{\text {high }} \text { Sca- } 1^{\text {high }} 150^{\text {high }} \\
\text { HSCs } \downarrow \\
\text { Peripheral blood } \\
\text { neutrophils } \downarrow \\
\text { Monocytes } \downarrow \\
\text { Leukocytes } \downarrow\end{array}$ & 26 \\
\hline $\begin{array}{l}\text { Metabolic } \\
\text { disorder } \\
\text { Prothrombosis }\end{array}$ & $\begin{array}{l}\text { C57BL/6j } \\
(2012) \\
\text { Plos One }\end{array}$ & $\begin{array}{l}\text { Immobilized } \\
\text { stress } \\
(2 \text { weeks })\end{array}$ & $\begin{array}{c}\text { AT1R } \\
\text { Antagonist } \\
\text { (Irbesartan: } \\
3 \text { or } 10 \mathrm{mg} / \mathrm{kg} / \text { day) }\end{array}$ & $\begin{array}{c}\text { Inflammation } \downarrow \\
\text { Angiotensinogen } \downarrow \\
\text { GTT (-) /ITT } \downarrow \\
\text { PAI-1/TF } \downarrow \text { MCP- } 1 \downarrow \\
\text { TNF- } \alpha / \text { IL-6 } \downarrow \\
\text { Free fatty acid } \downarrow \\
\text { GLUT4/IRS- } \uparrow \\
\text { APN } \uparrow\end{array}$ & $\begin{array}{c}\text { Macrophage } \\
\text { infiltration } \downarrow \\
\text { Insulin resistance } \downarrow\end{array}$ & 27 \\
\hline $\begin{array}{l}\text { Metabolic } \\
\text { disorder } \\
\text { Prothrombosis }\end{array}$ & $\begin{array}{c}\text { C57BL/6j } \\
(2016) \\
\text { Psychoneuroen- } \\
\text { docrinology }\end{array}$ & $\begin{array}{c}\text { Immobilized } \\
\text { stress } \\
\text { (2 weeks) }\end{array}$ & $\begin{array}{l}\text { DPP4 inhibitor } \\
\text { (alogliptin: } \\
15 \text { or } 45 \\
\text { mg/kg/day) }\end{array}$ & $\begin{array}{c}\text { Macrophages } \downarrow \\
\text { GTT/ITT } \downarrow \\
\text { 8-OHdG } \downarrow \\
\text { Nox4/MCP-1 } \downarrow \\
\text { PAI-1/TF } \downarrow \\
\text { TNF- } \alpha / \text { IL-6 } \downarrow \\
\text { GLUT4/IRS- } 1 \uparrow \\
\text { Plasma DPP4 } \downarrow \\
\text { APN/GLP-1 } \uparrow\end{array}$ & $\begin{array}{c}\text { Macrophage } \\
\text { infiltration } \downarrow \\
\text { Insulin resistance } \downarrow \\
\text { Prothrombotic state } \downarrow\end{array}$ & 29 \\
\hline $\begin{array}{l}\text { Metabolic } \\
\text { disorder } \\
\text { Hyperuricemia }\end{array}$ & $\begin{array}{l}\text { C57BL/6j } \\
(2017) \\
\text { Scientific } \\
\text { Reports }\end{array}$ & $\begin{array}{l}\text { Immobilized } \\
\text { stress } \\
\text { (2 weeks) }\end{array}$ & $\begin{array}{c}\text { OX inhibitor } \\
\text { (febuxostat: } 1 \text { or } 5 \\
\mathrm{mg} / \mathrm{kg} / \text { day) }\end{array}$ & $\begin{array}{c}\text { Plasma and tissue } \\
\text { OX/MDA/XOR activity } \downarrow \\
\text { NADPH oxidase } \\
\text { subunit mRNAs } \downarrow \\
\text { ROS production } \downarrow \\
\text { Mn-SOD mRNA } \uparrow \\
\text { Catalase mRNA } \uparrow \\
\text { Macrophages } \downarrow \\
\text { GTT/ ITT } \downarrow \\
\text { MCP-1 } \downarrow \text { PAI- } 1 / \text { TF } \downarrow \\
\text { TNF- } \alpha / \text { IL-6 } \downarrow \\
\text { GLUT4/IRS- } 1 \uparrow\end{array}$ & $\begin{array}{c}\text { Macrophage } \\
\text { infiltration } \downarrow \\
\text { Hyperuricemia } \downarrow \\
\text { Glucose } \\
\text { Dysmetabolism } \downarrow \\
\text { Prothrombotic state } \downarrow\end{array}$ & 30 \\
\hline $\begin{array}{l}\text { Vascular } \\
\text { aging } \\
\text { Atherosclerosis }\end{array}$ & $\begin{array}{l}\text { ApoE }{ }^{-/-} \text {mice } \\
\text { (KOR/Stm } \\
\text { Slc-ApoE }{ }^{\text {shl }} \text {, } \\
\text { BALB/c } \\
\text { background) } \\
\text { (2017) } \\
\text { International } \\
\text { Journal of } \\
\text { Cardiology }\end{array}$ & $\begin{array}{l}\text { Chronic } \\
\text { variable } \\
\text { stress } \\
\text { (12 weeks) }\end{array}$ & $\begin{array}{l}\text { DPP4 inhibitor } \\
\text { (anagliptin: } \\
30 \mathrm{mg} / \mathrm{kg} / \text { day) } \\
\text { APN neutralizing } \\
\text { antibody } \\
(450 \mu \mathrm{g} / \mathrm{kg} / \mathrm{day})\end{array}$ & $\begin{array}{c}\text { Plasma DPP4 } \downarrow \\
\text { APN/GLP-1 } \uparrow \\
\text { TLR2-/TLR-4 } \downarrow \\
\text { CXCR4/MCP-1 } \downarrow \\
\text { NADPH oxidase } \\
\text { subunit } \downarrow \\
\text { MMP-2/MMP-9 } \downarrow \\
\text { TIMP-1/TIMP-2 } \downarrow \\
\text { CatS/CatL/CatK } \downarrow\end{array}$ & $\begin{array}{c}\text { Vascular senescence } \downarrow \\
\text { Neovessel } \downarrow \\
\text { Lipid accumulation } \downarrow \\
\text { Collagen content } \uparrow \\
\text { Elastin broken } \downarrow \\
\text { SMC contents }(-)\end{array}$ & 31 \\
\hline
\end{tabular}


Table. Experimental Studies of Chronic Stressors on Vascular Aging, Angiogenesis, and Atherosclerosis (continued)

\begin{tabular}{|c|c|c|c|c|c|c|}
\hline $\begin{array}{l}\text { Diseases and } \\
\text { implications }\end{array}$ & $\begin{array}{c}\text { Animals } \\
\text { Publication } \\
\text { year/journal }\end{array}$ & Stressor & Treatment & Mechanism & $\begin{array}{l}\text { Morphological and } \\
\text { functional alterations }\end{array}$ & Ref. \\
\hline $\begin{array}{l}\text { Vascular } \\
\text { aging } \\
\text { Angiogenesis } \\
\text { Neovascularization }\end{array}$ & $\begin{array}{c}\text { C57BL/6j } \\
\mathrm{DPP}^{-/-} \text {rats } \\
\mathrm{APN}^{-/-} \text {mice } \\
(2017) \\
\text { Journal of } \\
\text { American Heart } \\
\text { Association }\end{array}$ & $\begin{array}{l}\text { Chronic } \\
\text { variable } \\
\text { stress } \\
\text { (4 weeks) }\end{array}$ & $\begin{array}{c}\text { Anagliptin } \\
\text { (low: } 30 \mathrm{mg} / \mathrm{kg} / \\
\text { day; high: } 60 \mathrm{mg} / \\
\mathrm{kg} / \text { day }) \\
\text { Exenatide } \\
(5 \mu \mathrm{g} / \mathrm{kg} / \text { day }) \\
\mathrm{APN} \\
\text { neutralizing } \\
\text { antibody } \\
\text { (450 } \mathrm{mg} / \mathrm{kg} / \text { day })\end{array}$ & $\begin{array}{c}\text { Plasma DPP4 } \downarrow \\
\text { Corticosterone } \uparrow \\
\text { GLP-1/APN } \uparrow \\
\text { p-APMK } \alpha / \text { Sirt- } 1 \uparrow \\
\text { PPAR- } \gamma / \text { PGC-1 } \alpha \uparrow \\
\text { VEGF } \uparrow \\
\text { MMP-2/MMP-9 } \downarrow \\
\text { GLUT4/IRS-1 } \uparrow \\
\text { Macrophages } \downarrow\end{array}$ & $\begin{array}{c}\text { Blood flow } \uparrow \\
\text { Capillary density } \uparrow \\
\text { Amputation } \uparrow \\
\text { Inflammation } \downarrow\end{array}$ & 40 \\
\hline Vascular aging & $\begin{array}{l}\text { C57BL/6j } \\
(2019) \\
\text { Chemico- } \\
\text { Biological } \\
\text { Interactions }\end{array}$ & $\begin{array}{c}\text { Chronic } \\
\text { immobilized } \\
\text { stress } \\
\text { (2 weeks) }\end{array}$ & $\begin{array}{c}\text { Anagliptin } \\
\text { (30 mg/kg/day) }\end{array}$ & $\begin{array}{c}\text { Plasma DPP4 } \downarrow \\
\text { eNOS/Sirt1 } \uparrow \\
\text { p53/p21/p27 } \downarrow \\
\text { gp91 phox/p22 phox } \downarrow \\
\text { MMP-2/MMP-9 } \downarrow \\
\text { CatS/CatL/CatK } \downarrow\end{array}$ & Vascular aging $\downarrow$ & 41 \\
\hline $\begin{array}{l}\text { Vascular } \\
\text { aging } \\
\text { Atherosclerosis }\end{array}$ & $\begin{array}{l}\text { ApoE }{ }^{-/-} \text {mice } \\
\text { (KOR/Stm } \\
\text { Slc-ApoE }{ }^{\text {shl }} \text {, } \\
\text { BALB/c back- } \\
\text { ground) } \\
\text { (2017) } \\
\text { Atherosclerosis }\end{array}$ & $\begin{array}{l}\text { Chronic } \\
\text { variable } \\
\text { stress } \\
\text { (12 weeks) }\end{array}$ & $\begin{array}{c}\text { GLP-1 analogue } \\
\text { (exenatide: } \\
5 \mu \mathrm{g} / \mathrm{kg} / \text { day) }\end{array}$ & $\begin{array}{c}\text { Plasma APN/leptin } \uparrow \\
\text { eNOS } \uparrow \\
\text { TLR2-/TLR-4 } \downarrow \\
\text { CXCR4/SDF-1 } \downarrow \\
\text { gp91 } \\
\text { MMPox/p22 phox } \downarrow \\
\text { TIMP-1/TIMP-2 } \downarrow \\
\text { CatS/CatL/CatK } \downarrow\end{array}$ & $\begin{array}{c}\text { Vascular senescence } \downarrow \\
\text { Neovessel } \downarrow \\
\text { Lipid accumulation } \downarrow \\
\text { Collagen content } \uparrow \\
\text { Elastin broken } \downarrow \\
\text { SMC contents }(-)\end{array}$ & 42 \\
\hline
\end{tabular}

7ND indicates dominant negative mutation of monocyte chemoattractant protein-1; MCP-1, monocyte chemoattractant protien-1; HSC, hematopoietic stem cell; Adr $\beta 3$, $\beta 3$ adrenaline receptor; AT1R, angiotensin II type 1 receptor; VEGF, vascular endothelial growth factor; p-Erk1/2, phosphate-extracellular signal regulated kinase-1/-2; OX, xanthine oxidase; GTT, glucose tolerance test; ITT, insulin tolerance test; 8-OHdG, 8-hydroxy-2'-deoxyguanosine; PAI-1, plasminogen activator-1; TF, tissue factor; GLUT4, glucose transporter type 4; TNF- $\alpha$; tumor necrosis factor- $\alpha$; IL-6, interleukin-6; GLP-1, glucagon-like peptide-1, DPP-4, dipeptidyl peptidase-4, APN, adiponectin; MDA, lipid peroxidation; NADPH, nicotinamide adenine dinucleotide phosphate; ROS, reactive oxygen species; XOR, xanthine oxidoreductase; Mn-SOD, Mn-superoxide dismutase; SMCs, smooth muscle cells; CatS, cathepsin S; MMP-2, matrix metalloproteinase-2; CXCR4, C-X-C chemokine receptor type 4; SDF-1, stromal derived factor-1; eNOS, endothelial nitric oxide synthase; p-AMPK $\alpha$, phospho-AMP-activated protein kinase $\alpha$; PPAR- $\gamma$; peroxisome proliferator-activated receptor- $\gamma$; PGC- $1 \alpha$, PPAR- $\gamma$ co-activator; DPP4 ${ }^{-/-}$, DPP4 deficiency; ApoE ${ }^{-/}$, apolipoprotein deficiency; APN ${ }^{-/}$, adiponectin deficiency; Ref., reference; $(-)$, no change; $\uparrow$, increase; and $\downarrow$, decrease or improvement.

quiescent cell proline dipeptidase, thymus-specific serine protease, attractin, and other DPP-4 activity and/or structural homologues. ${ }^{15)}$ The adenosine deaminase immunoaffinity chromatography assay showed that soluble CD26/ DPP-4 was responsible for the release of X-pro dipeptides. ${ }^{16)}$ Accumulating evidence suggests that the assessment of selectivity of potential clinical candidates may be important to create an optimal safety profile for this new class of antihyperglycemic agents. ${ }^{17,18)}$

DPP-4 is a widely expressed glycoprotein that has attracted much attention both as a receptor for the Middle Eastern respiratory syndrome virus and for its role in the proteolytic degradation of gastrointestinal hormones, such as glucose-dependent insulinotropic polypeptide and glucagon-like peptide-1 (GLP-1). ${ }^{14)}$ DPP-4 consists of three structural domains: a transmembrane $\alpha$-helix domain, a C-terminal extracellular domain, and an $\mathrm{N}$ terminal intracellular domain. ${ }^{19}$ Iwaki-Egawa and colleagues reported that the $\mathrm{N}$-terminal intracellular domain contributes to the enzymatic activity, ${ }^{20)}$ and it was later demonstrated that the transmembrane region is responsible for the main enzymatic activity. ${ }^{19)}$ In addition to the transmembrane domain, DPP-4 presents as a soluble form, which is the extracellular domain of the peptide considered to be cleaved from the cell plasma membrane. ${ }^{19}$
Since being identified, DPP-4- also known as T-cell activation antigen CD26 or Adenosine deaminase-binding protein 2 -was known to be a 766-amino acid serine exopeptidase belonging to the S9B protein family and to degrade two alanine or X-proline dipeptides from the $\mathrm{N}$ terminus of polypeptides in the extracellular space. ${ }^{21)}$ DPP4 has been reported to be widely expressed on cell surface peptidase, which has a complex biology, participating in the cell membrane-related activation of cell-cell cross-talk, intracellular signal transductions, and the proteolytic activity displayed by the membrane-anchored and soluble forms of the enzyme. ${ }^{22,23)}$ Over the last 10 years, emerging findings demonstrated unexpected roles of DPP-4 in intracellular signaling, oxidative stress production, lipid metabolism, insulin resistance, immune activation, and inflammation. ${ }^{24,25)}$ These activities provide a broad range of molecular functions of the DPP-4 family (Figure 1), with clinical implications for a potential pathophysiological role in metabolic and inflammatory CVDs. Recent data from laboratory and clinical studies highlighted the role of DPP family members (especially DPP-4) in ACVD. ${ }^{26-28)}$

Cell and tissue expression of DPP-4: DPP-4, which is one of the most potent serine peptidases, is broadly expressed in mammalian tissues, including the kidney, blood vessels, small intestine, lung, liver, brain, spleen, adipose, 


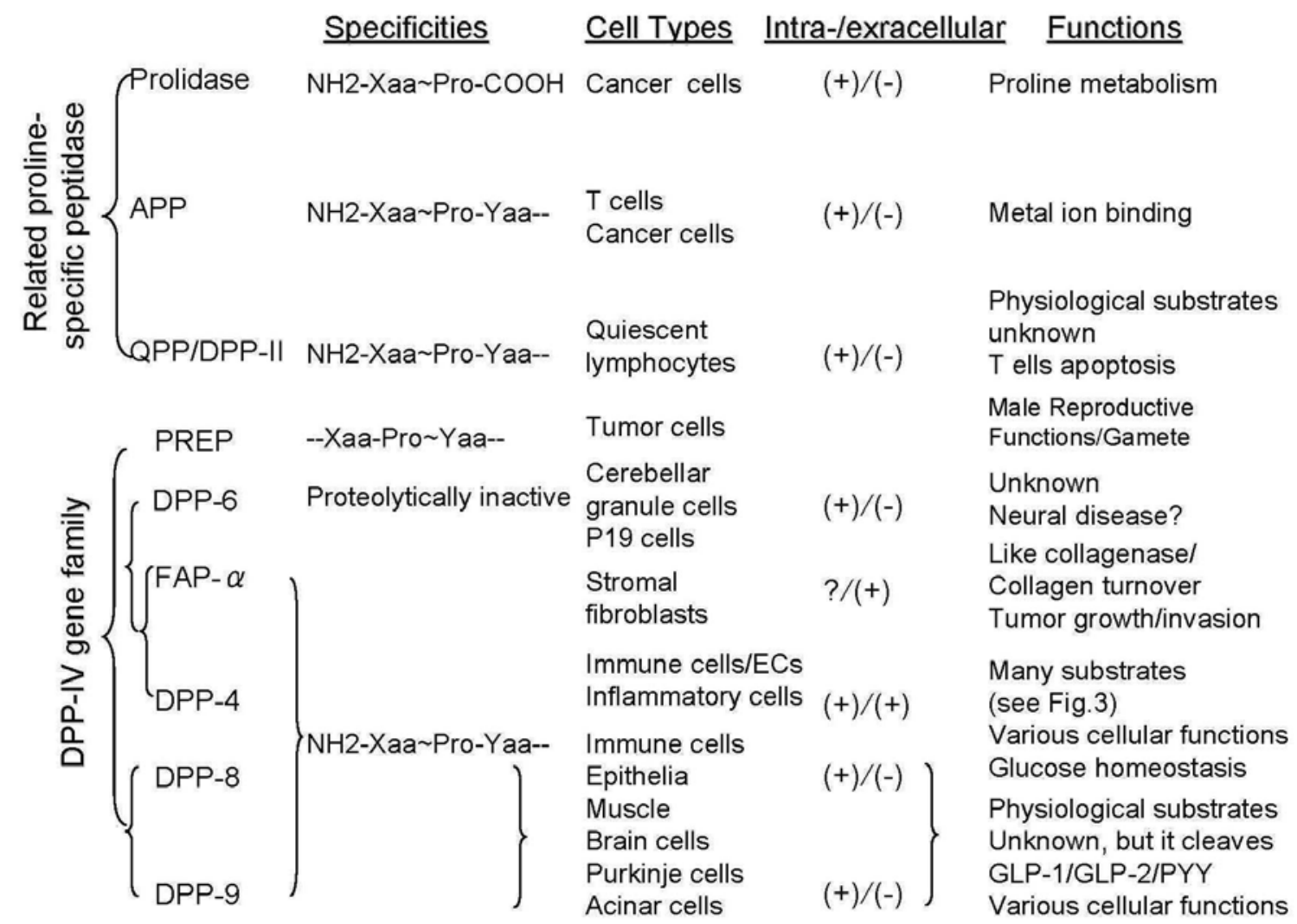

Figure 1. The substrate specificities, cell expression, working spaces, and functions of the family of DPP-4-related enzymes. ECs indicates endothelial cells; FAP- $\alpha$, fibroblast activation protein- $\alpha$; APP, aminopeptidase P; QPP, quiescent cell praline dipeptidase; PREP, prolyl endopeptidase; GLP, glucagon-like peptide; PYY, peptide YY; (+), working in intra- or extracellular space; (-), not working in intra- or extracellular space; and ?, unknown.

and heart tissues (Figure 2). ${ }^{10)}$ The observations of an early experimental study using colorimetric enzyme histochemistry demonstrated that DPP-4 activity is localized in cardiac venous capillaries. DPP-4 is also expressed on endothelial progenitor cells, endothelial cells, some important immune cells (e.g., monocytes, dendritic cells, natural killer cells, and lymphocytes) and inflammatory cells (i.e., macrophages) in various pathological conditions. ${ }^{14,19)}$ As it is distributed widely, DPP-4 inhibition is a promising approach in various medical fields, such as inflammation regulation, hematopoiesis recovery, and immunomodulation, and, of course, in vascular repair and ischemic $\mathrm{ACVD},{ }^{27,29,30)}$ as highlighted in this review.

\section{DPP-4 Substrates}

Numerous neuropeptides, hormones, chemokines, growth factors, and endocrines contain an alanine or proline at position 2 and are putative DPP-4 substrates. DPP-4 exhibits many physiological and pharmacological functions by truncating extremely abundant substrates. ${ }^{19)}$ It is well known that DPP-4 inhibition can enhance insulin secretion and improve glucose tolerance in humans via the GLP-1-dependent signaling pathway. ${ }^{31}$ Synthetic DPP-4 inhibitors were also reported to ameliorate glucose intolerance in Glplr $^{-1-}$ mice, ${ }^{32)}$ suggesting that DPP-4 exerts its own biological role, independent of GLP-1. In addition,
DPP-4 degrades a large number of peptide chemokines and hormones in vitro, whereas comparatively limited peptides have been characterized as endogenous physiological substrates for DPP-4 in vivo. ${ }^{14)}$ Based on DPP-4's potential catalytic activity in vivo and in vitro, it seems that the proteins/peptides with cleavage sites for DPP-4 could be potential substrates of DPP-4 in various pathophysiological conditions.

Accumulating evidence indicates putative praline or N-terminal alanine DPP-4 truncation sites in many chemokines, cytokines, growth factors, and hormones, for example, interleukin-3 (IL-3), IL-1 $\alpha$, IL-6, colonystimulating factor (CSF), stromal cell-derived factor- $1 \alpha$, granulocyte-CSF, granulocyte macrophage-CSF, erythropoietin, a number of splice variants of vascular endothelial growth factor-A, leukemia inhibitory factor, thrombopoietin, high-mobility group box 1 , and others. ${ }^{19)}$ This raises the possibility that DPP-4 can modulate ACVD initiation and progression through the degradation and modification of these substrate-related factors. Given the potential effects of DPP-4 on ACVD, DPP-4 inhibitors have recently been known as pharmacological targets for ischemic ACVD. In the following sections, we focus on the significance of DPP-4/its inhibitor-mediated cardiovascular benefits on vascular inflammatory and metabolic CVDs in animals and humans under CPS. 


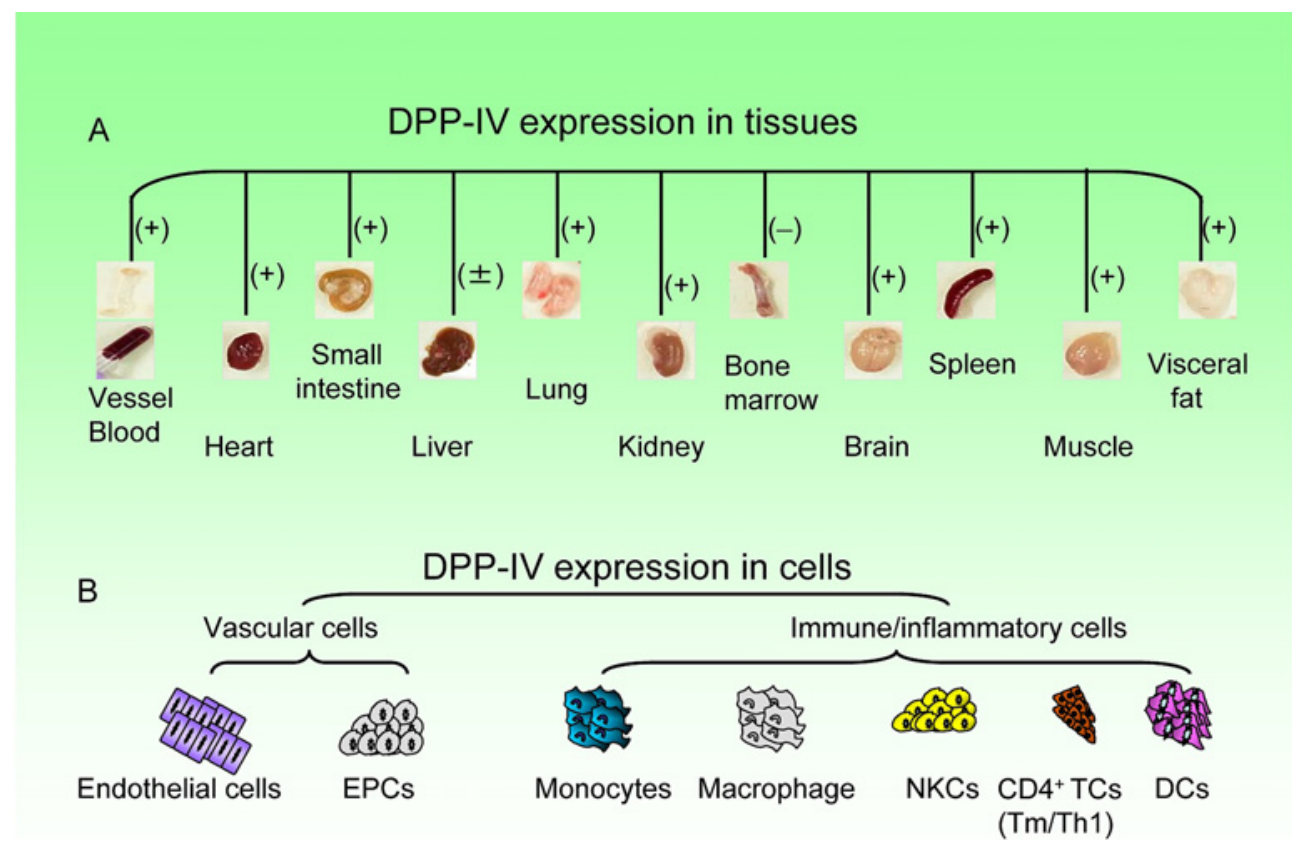

Figure 2. Dipeptidyl peptidase-4 (DPP-4) is known to be expressed widely in human and animal tissues (e.g., vessels, blood, heart, small intestine, lung, kidney, brain, spleen, muscle, and visceral fat) (A) and vascular cells and ischemic cardiovascular disease (ICVD) -associated cells (B). EPCs indicates endothelial progenitor cells; NKCs, natural killer cells; TCs, T cells; Tm/Th1, T-memory/T-helper; DC, dendritic cells; $(+)$, increase in diseased tissues; $( \pm$ ), increase/no changes in diseased tissue; and (-), no detection.

\section{The Impact of CPS on ACVD and Its Mechanisms}

Stress produces plasma and tissue DPP-4 and GLP-1 imbalance: Individual DPP family members may participate in inflammatory and metabolic disorders. ${ }^{33,34)}$ The importance of DPP-4 in the initiation and progression of ACVD and the data on DPP-4 inhibition-mediated beneficial effects obtained from experimental models, mechanistic human studies, and clinical trials are summarized in two early comprehensive reviews. ${ }^{19,31)}$ The discovery of incretin-based treatments exhibits a major therapeutic advance in the medical intervention of cardiometabolic disorders, and the development of DPP-4 inhibitors as useful antidiabetic drugs was based on the concept that these agents would enhance systematic and tissue glucagon-like peptide-1 (GLP-1) levels, causing an improvement of the insulinotropic effects of blood sugar. ${ }^{35,36)}$ In addition to GLP-1-dependent effects on the cardiometabolic risk profile, DPP-4 inhibitors provide vascular protective beneficial effects by modulating several substrate factor activities (e.g., CSF, stromal cell-derived factor- $1 \alpha$, granulocyte-CSF, granulocyte macrophage-CSF, neuropeptide $\mathrm{Y}$, and high-mobility group box 1). ${ }^{37)}$ A clinical study reported that individuals with and without DM had increased plasma DPP-4 levels and decreased plasma GLP-1 levels. ${ }^{38)}$ In mice and rats, chronic stress increased circulating and tissue DPP-4 activities and decreased plasma and brain GLP-1 levels, ${ }^{2,26,27)}$ suggesting an imbalance between GLP-1 and DPP-4 as a potential therapeutic target in the management of vascular aging and atherosclerosis in animals under experimental stress conditions.

DPP-4 inhibition attenuated vascular aging and athe- rosclerosis via the reduction of inflammation and oxidative stress production associated with GLP-1mediated adiponectin production in response to stress: Although a growing body of evidence indicates that DPP4 plays an important role in the initiation and progression of ACVD ${ }^{19)}$ little is known about the functional relevance of this exopeptidase as a transmembrane protease in the pathogenesis of stress-related vascular senescence and atherogenesis. Chronic variable stress has been exhibited to produce harmful changes in blood and tissue DPP-4 levels. ${ }^{10,39)}$ It is well known that inflammation occurs in all stages of atherosclerosis, including initiation, progression, calcification, plaque rupture, and ultimately, thrombotic complications. ${ }^{40)}$ Data from our research team and those from other groups clearly revealed that chronic variable stress activated bone-marrow hematopoietic stem cell proliferation via the inactivation of $\beta$-adrenergic receptormediated C-X-C motif chemokine 12 (CXCL12) (Table), leading to an increased output of inflammatory monocytes and neutrophils (Figure 3). ${ }^{9,10)}$ Existing evidence has confirmed that stress can increase inflammatory actions in vascular and adipose tissues. ${ }^{2,4}$ In vivo, marked increases in neutrophil and macrophage infiltration and inflammatory chemokine/cytokine expressions (i.e., monocyte chemoattractant protein-1, osteopontin, toll-like receptor, and CXCR4) and vascular aging were observed in the aortas of stressed mice, and these changes were rectified significantly by DPP-4 inhibitor anagliptin treatment (Figure 3$)^{27}$

Accumulating evidence suggests that oxidative stress also plays a critical role in vascular senescence and atherosclerotic plaques in animals and humans. ${ }^{41)}$ The observa- 


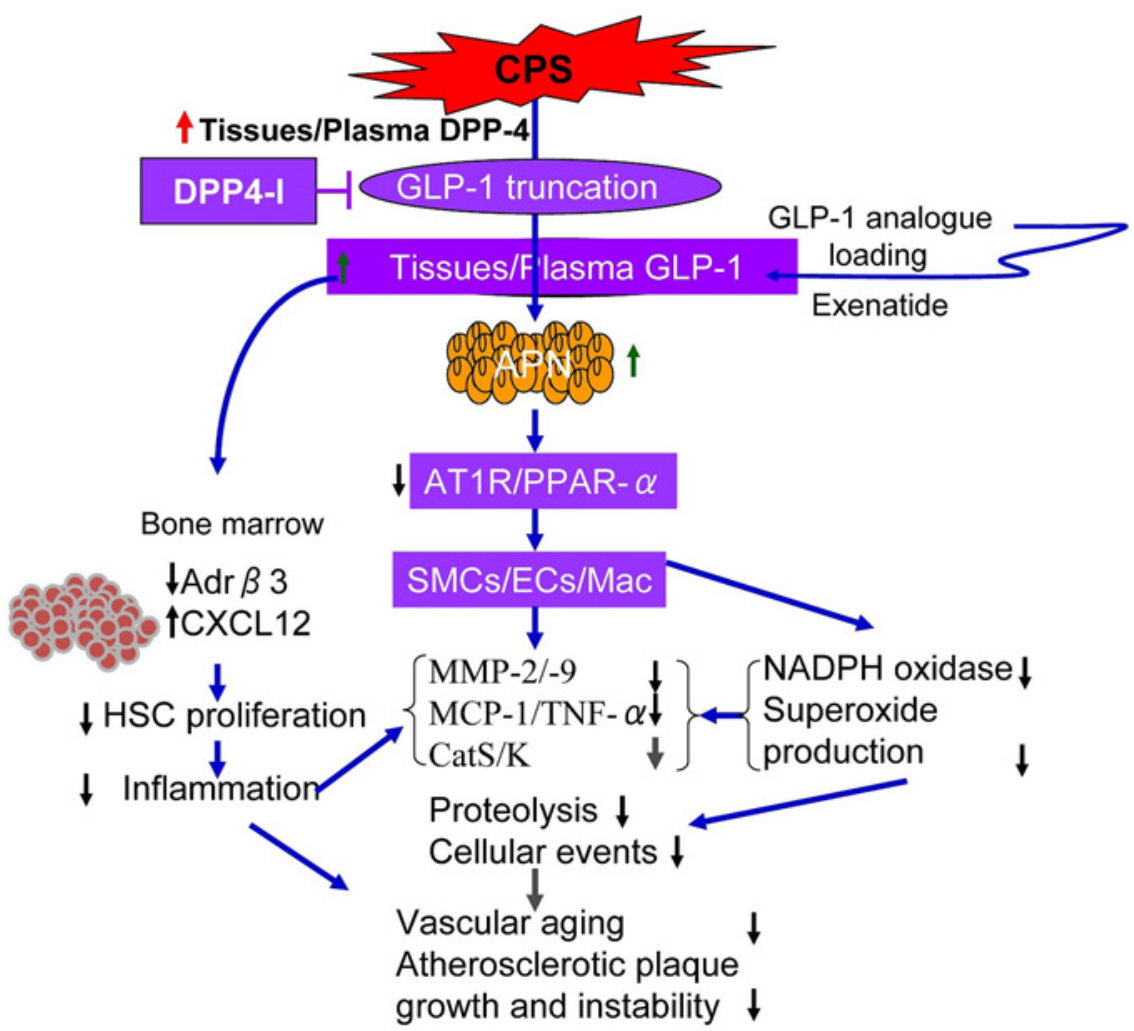

Figure 3. The proposed mechanisms of how GLP-1R activation and DPP-4 inhibition suppress stress-related vascular endothelial senescence and atherosclerotic lesion formation in mice fed a high-fat diet. Stress enhanced the levels of blood DPP-4 levels and decreased blood GLP-1, which decreased adipose APN expression and promoted atherosclerotic lesion oxidative stress production, inflammation, and proteolysis, leading to an acceleration of vascular senescence and atherosclerotic lesion formation and its instability in ApoE ${ }^{-/-}$mice. CPS indicates chronic psychological stress; DPP-4, dipeptidyl peptidase-4; APN, adiponectin; PPAR- $\gamma$, peroxisome proliferator-activated receptor- $\gamma$; Adr $\beta 3, \beta 3$ adrenaline receptor; GLP-1R, GLP-1 receptor; PGC- $1 \alpha$, PPAR- $\gamma$ co-activator-1 $\alpha$; GLP-1, glucagon-like peptide-1; SMCs, smooth muscle cells; ECs, endothelial cells; Mac, macrophages; HSC, hematopoietic stem cell; MMP-2, matrix metalloproteinase-2; and CatS, cathepsin S.

tions described herein exhibit that anagliptin mitigated NADPH oxidase component expression (p22phox, p47 phox, p67phox, and gp91phox) and superoxide (O2-) generation. Moreover, the levels of the adiponectin protein and gene were increased in the blood, inguinal, and subcutaneous adipose tissues of stressed apoE lipoproteindeficient $(\mathrm{ApoE})^{-/-}$mice, and these changes were reversed by DPP-4 inhibition. ${ }^{27)}$ In vitro, the GLP-1 analog exenatide increased adiponectin expression in adipose tissuederived immature adipocytes in a dose-dependent manner, whereas anagliptin did not affect it. ${ }^{27)}$ Surprisingly, adiponectin depletion with its neutralizing antibody almost completely diminished the anagliptin-mediated vascular benefits in $\mathrm{ApoE}^{-/-}$mice fed a high-fat diet. ${ }^{27)}$ Adiponectin was protective against various vascular injuries under conditions of stress. ${ }^{42)}$ These findings thus indicate that an enhancement of GLP-1 by DPP-4 inhibition may have provided a positive modulation of vascular senescence and atherosclerotic lesion formation through the improvement of adiponectin-induced antioxidative stress production and anti-inflammation in $\mathrm{ApoE}^{-/}$mice under our experimental conditions (Figure 3). This notion was further supported by the findings of a comparable effect of exenatide on stress-related vascular harmful changes in $\mathrm{ApoE}^{-/-}$mice fed a high fat-diet. ${ }^{39)}$

DPP-4 inhibition prevents stress-related atherosclerotic plaque growth via the reduction of proteolysis: Accumulating evidence of vascular cells have reported that atherosclerosis-associated inflammatory cytokines augment the expression and production of the members of cathepsin and matrix metalloproteinase (MMP) families from cultured vascular cells (i.e., vascular smooth muscles and endothelial cells), monocyte-derived macrophages, mast cells, and $\mathrm{T}$ lymphocytes, and that these inflammatory cytokines increase the degradation of extracellular matrix proteins (collagen and elastin). ${ }^{43)}$ Novel insights into the actions of these proteases have been made possible by the generation and in-depth analyses of transgenic and knockout mice. ${ }^{44)}$ It is well known that both cathepsin and MMP activities modulate neovascularization and vascular remodeling through the modification, activation, and liberation of cytokines, angiogenic growth factors, cell events (apoptosis, transmigration, and proliferation), neovascularization, and matrix protein metabolism. ${ }^{43}$ Pharmacological 
inhibitors targeting GLP-1 receptor stimulation and DPP-4 activity exhibited a protective effect on the expression and/or activities of proteolytic enzymes [e.g., cathepsin L (CatL), CatS, CatK, matrix metalloproteinase-2 (MMP-2), and MMP-9] and matrix protein metabolism (elastin and collagen) in the lesions of stressed animals fed a high-fat diet. $^{2,27,39)}$ These therapies also suppressed the levels of plaque peroxisome proliferator-activated receptor- $\alpha$ (PPAR- $\alpha$ ) and angiotensin II type 1 receptor (AT1R) proteins. ${ }^{27)}$ Both receptor systems with their ligands have been exhibited to regulate $\mathrm{CatS} / \mathrm{K}$ and MMP-2/-9 expression by the enhanced productions of oxidative stress and inflammatory cytokines both in vivo and in vitro. ${ }^{43)}$ In vitro, exenatide suppressed tumor necrosis factor-alpha expression in cultured macrophages. These findings thus suggest that atherosclerotic lesion development with neovascularization and instability may be attributable to the increase in MMP-2/-9- and CatL/S/K-mediated proteolysis induced by the stimulation of PPAR- $\alpha$ - and AT1Rsignaling pathway-related oxidative stress production and inflammation in animals under chronic stress conditions (Figure 3).

DPP-4 inhibition and GLP-1 receptor activation attenuated atherosclerosis via the modification of lipid metabolism: Previous clinical and basic research studies indicated that GLP-1 and DPP-4 activities are involved in lipid metabolism..$^{27,31,39)}$ Biological analyses demonstrated that anagliptin reduced blood nonesterified fatty acids and triglycerides in stressed animals, ${ }^{27)}$ and similar results were found in stressed animals treated with exenatide. ${ }^{39)}$ Exenatide dramatically reduced the foam cell formation of peripheral blood monocyte-derived macrophages. ${ }^{39)}$ Clinical observations have provided a limited beneficial effect of DPP-4 inhibition on plasma apolipoprotein B-48 and triglyceride levels. ${ }^{31)}$ Therefore, the improvements in free fatty acid and triglyceride metabolism may also contribute to the incretin-based glucose-lowering drug-related vascular benefits in mice under stress. Unfortunately, we observed that these treatments did not alter plasma levels of "good" and "bad" cholesterols (i.e., high- and low-density lipoprotein cholesterols) in animals under our experimental stress conditions. ${ }^{27,39)}$ However, clinical research provides evidence that these preclinical observations are translated into clinical practice. ${ }^{45}$

\section{Clinical Trials with DPP-4 Inhibitors in CVD}

Incretin-based DPP-4 inhibitors are often the chosen antidiabetic medications that are now most widely used globally. The outcomes of several clinical trials to evaluate the cardiovascular safety of DPP-4 inhibitors have been reported. ${ }^{46-49)}$ SAVOR-TIMI53 was designed as a superiority trial and failed to meet the prespecified superior outcomes of saxagliptin versus placebo in a high-risk patient population with established vascular diseases and risk factors. ${ }^{46)}$ In the EXAMINE trial, designed as a safety trial in a high-risk population with post-acute coronary syndrome, the prespecified end point of non-inferiority was met, and alogliptin was non-inferior to the placebo with regard to cardiovascular outcomes. ${ }^{47)}$ Despite the many preclinical studies showing the beneficial effects of incretin-related drugs, most cardiovascular safety trials of incretin-based DPP-4 inhibitors did not show benefits for cardiovascular events. It is important to recognize that cardiovascular safety trials were carried out to meet the US Food and Drug Administration guidance to assess cardiovascular safety of all new antidiabetic drugs; they were not designed to assess their benefits for cardiovascular events. Therefore, the long-term potential benefits, as well as the safety, of DPP-4 inhibitors for certain cardiovascular outcomes have not been definitively established, and must be evaluated in more specific and relevant trials. If the need for cardiovascular safety trials is determined based on an individual drug's safety data during its early development as well as its mechanism of action, resources could be saved when carrying out such clinical trials.

In addition, these negative clinical findings are inconsistent with the positive results of animal studies, ${ }^{10,12,26,27)}$ which demonstrated a DPP-4 inhibitor-mediated cardiovascular protective effect in animal studies. Although based on their exclusion and inclusion criteria, these large-scare clinical trials recruited huge numbers of participants with different conditions (e.g., age, sex, body mass index, medical and medication histories, etc.), especially, ACVD risk factors and its complications. ${ }^{46-49)}$ In contrast, in animal studies, DPP-4 inhibitors were applied to investigate whether they produce a cardiovascular beneficial effect in various special simplified animal models (e. g., an ischemia-induced hindlimb model, a carotid artery ligation with and without cuff-replacement model, a myocardial infarction model, or a diet-induced atherosclerosis model) or model mice (ApoE ${ }^{-/-}$mice, etc.). ${ }^{14)}$ With the exception of the vehicle and drugs used, the animal conditions (e.g., age, sex, body weight, genetic background, etc.) were controlled to be the same or similar between experimental groups. These factors possibly explain the inconsistent DPP-4 inhibitor-mediated cardiovascular effects between humans and animals. Further studies will be needed to investigate this issue.

\section{Plasma DPP-4, GLP-1, and Adiponectin Levels as Novel Biomarkers for Chronic Stress and Related CVD Risk}

Recently, it was reported that increased circulating DPP-4 and decreased circulating adiponectin and GLP-1 might serve as new useful biomarkers to predict the presence of stress in animals. ${ }^{10,26)}$ The observations suggest that among these biological parameters, blood DPP-4 levels were more sensitive to chronic stress, and that the noninvasive evaluation of those alterations would be useful to assess brain injuries in animals subjected to chronic stress. ${ }^{10)}$ However, the clinical significance of targeted hormone and exopeptidase changes in the initiation and progression of ACVD associated with modern stressors in humans (including natural disasters, environmental stress, work-related stress, and social anxiety) should be studied as large-scale prospective and/or retrospective cohort studies. 


\section{Concluding Remarks}

Overall, recent findings from Lei, et al. suggest a potential clinically applicable benefit of DPP-4 inhibitors on vascular senescence and atherogenesis in $\mathrm{ApoE}^{-/-}$mice under experimental stress conditions, ${ }^{27}$ ) with an effect size similar to that of GLP-1 analog-based therapies. ${ }^{39)}$ This protective effect is supported by the finding of a consistent effect of genetic inhibition targeting DPP-4 on inflammation cell production and cytokine expression in the peripheral blood of rats under chronic stress. ${ }^{10)}$ These results are consistent with the positive findings of a small clinical trial of a GLP-1 analog or DPP-4 inhibitor as a useful treatment to mitigate atherosclerotic lesion formation and coronary artery events in patients with ACVD with and without DM. ${ }^{36,50)}$ Nevertheless, given the safety profile of DPP-4 inhibitors and most current, near-term clinical trial data, these intriguing data make a compelling case for long-term observational studies of GLP-1 analogs and DPP-4 inhibitors on CPS-related ACVD. There are some limitations to these current observations as follows: (1) The absence of preclinical dose dependence when comparing dose administration at 30,60 , and $90 \mathrm{mg} / \mathrm{kg} /$ day; (2) the use of DPP-4 inhibitors in T1DM and T2DM under physiological or psychological stress has not been studied rigorously in long-term, randomized clinical trials; (3) cardiovascular safety endpoints (e.g., chronic heart failure, hospitalization, sudden death) have been studied rigorously, ${ }^{46)}$ but long-term data may be more challenging to interpret; and (4) the chronic immobilized stress model used in these studies could not completely mimic human CPS. Thus, it is too hard to fully explore the mechanism of CPS-related CVD and these drug-mediated cardiovascular benefits using these animal models.

\section{Disclosure}

Conflicts of interest: The authors declare that they have no conflicts of interest to disclose with respect to this manuscript.

\section{References}

1. Lagraauw HM, Kuiper J, Bot I. Acute and chronic psychological stress as risk factors for cardiovascular disease: Insights gained from epidemiological, clinical and experimental studies. Brain Behav Immun 2015; 50: 18-30.

2. Xin M, Jin X, Cui X, et al. Dipeptidyl peptidase-4 inhibition prevents vascular aging in mice under chronic stress: Modulation of oxidative stress and inflammation. Chem Biol Interact 2019; 314: 108842.

3. Jin $\mathrm{X}$, Jin $\mathrm{C}$, Nakamura $\mathrm{K}$, et al. Increased dipeptidyl peptidase4 accelerates chronic stress-related thrombosis in a mouse carotid artery model. J Hypertens 2020; 38: 1504-13.

4. Wang H, Meng X, Piao L, et al. Cathepsin S deficiency mitigated chronic stress-related neointimal hyperplasia in mice. J Am Heart Assoc 2019; 8: e011994.

5. Meng X, Piao L, Wang H, et al. Deficiency of cysteinyl cathepsin $\mathrm{k}$ suppresses the development of experimental intimal hyperplasia in response to chronic stress. J Hypertens 2020; 38: 1514-24

6. Rosengren A, Hawken S, Ounpuu S, et al. Association of psy- chosocial risk factors with risk of acute myocardial infarction in 11119 cases and 13648 controls from 52 countries (the interheart study): Case-control study. Lancet 2004; 364: 953-62.

7. Arnold SV, Smolderen KG, Buchanan DM, Li Y, Spertus JA. Perceived stress in myocardial infarction: Long-term mortality and health status outcomes. J Am Coll Cardiol 2012; 60: 175663.

8. Steptoe A, Kivimäki M. Stress and cardiovascular disease. Nat Rev Cardiol 2012; 9: 360-70.

9. Heidt T, Sager HB, Courties G, et al. Chronic variable stress activates hematopoietic stem cells. Nat Med 2014; 20: 754-8.

10. Zhu E, Hu L, Wu H, et al. Dipeptidyl peptidase-4 regulates hematopoietic stem cell activation in response to chronic stress. J Am Heart Assoc 2017; 6.

11. Yisireyili M, Uchida Y, Yamamoto K, et al. Angiotensin receptor blocker irbesartan reduces stress-induced intestinal inflammation via atla signaling and ace2-dependent mechanism in mice. Brain Behav Immun 2018; 69: 167-79.

12. Yisireyili M, Takeshita K, Hayashi M, et al. Dipeptidyl peptidase- iv inhibitor alogliptin improves stress-induced insulin resistance and prothrombotic state in a murine model. Psychoneuroendocrinology 2016; 73: 186-95.

13. Abbott CA, Baker E, Sutherland GR, McCaughan GW. Genomic organization, exact localization, and tissue expression of the human CD26 (dipeptidyl peptidase IV) gene. Immunogenetics 1994; 40: 331-8.

14. Lei Y, Hu L, Yang G, Piao L, Jin M, Cheng X. Dipeptidyl peptidase-iv inhibition for the treatment of cardiovascular disease- recent insights focusing on angiogenesis and neovascularization. Circ J 2017; 81: 770-6.

15. Yu DM, Yao TW, Chowdhury S, et al. The dipeptidyl peptidase IV family in cancer and cell biology. FEBS Journal 2010; 277: 1126-44.

16. Durinx C, Lambeir AM, Bosmans E, et al. Molecular characterization of dipeptidyl peptidase activity in serum: Soluble CD26/ dipeptidyl peptidase IV is responsible for the release of $\mathrm{x}$-pro dipeptides. Eur J Biochem 2000; 267: 5608-13.

17. Lankas GR, Leiting B, Roy RS, et al. Dipeptidyl peptidase IV inhibition for the treatment of type 2 diabetes: Potential importance of selectivity over dipeptidyl peptidases 8 and 9. Diabetes 2005; 54: 2988-94.

18. Havale SH, Pal M. Medicinal chemistry approaches to the inhibition of dipeptidyl peptidase- 4 for the treatment of type 2 diabetes. Bioorg Med Chem 2009; 17: 1783-802.

19. Zhong J, Maiseyeu A, Davis SN, Rajagopalan S. Dpp4 in cardiometabolic disease: Recent insights from the laboratory and clinical trials of dpp4 inhibition. Circ Res 2015; 116: 1491-504.

20. Iwaki-Egawa S, Watanabe Y, Kikuya Y, Fujimoto Y. Dipeptidyl peptidase IV from human serum: Purification, characterization, and N-terminal amino acid sequence. J Biochem 1998; 124: 428-33.

21. Matteucci E, Giampietro O. Dipeptidyl peptidase-4 (CD26): Knowing the function before inhibiting the enzyme. Curr Med Chem 2009; 16: 2943-51.

22. Deacon CF. Metabolism of gip and the contribution of gip to the glucose-lowering properties of dpp-4 inhibitors. Peptides 2020; 125: 170196.

23. Gupta S, Sen U. More than just an enzyme: Dipeptidyl peptidase-4 (dpp-4) and its association with diabetic kidney remodelling. Pharmacol Res 2019; 147: 104391.

24. Sato H, Kubota N, Kubota T, et al. Anagliptin increases insulininduced skeletal muscle glucose uptake via an no-dependent mechanism in mice. Diabetologia 2016; 59: 2426-34.

25. Fleenor BS, Ouyang A, Olver TD, et al. Saxagliptin prevents increased coronary vascular stiffness in aortic-banded mini swine. Hypertension 2018; 72: 466-75.

26. Piao L, Zhao G, Zhu E, et al. Chronic psychological stress accelerates vascular senescence and impairs ischemia-induced neovascularization: The role of dipeptidyl peptidase-4/glucagonlike peptide-1-adiponectin axis. J Am Heart Assoc 2017; 6. 
27. Lei Y, Yang G, Hu L, et al. Increased dipeptidyl peptidase-4 accelerates diet-related vascular aging and atherosclerosis in apoedeficient mice under chronic stress. Int J Cardiol 2017; 243: 413-20.

28. Cosenso-Martin LN, Takaoka LY, Vilela-Martin JF. Randomized study comparing vildagliptin vs glibenclamide on glucose variability and endothelial function in patients with type 2 diabetes mellitus and hypertension. Diabetes Metab Syndr Obes 2020; 13: 3221-9.

29. Broxmeyer HE, Hoggatt J, O'Leary HA, et al. Dipeptidylpeptidase 4 negatively regulates colony-stimulating factor activity and stress hematopoiesis. Nat Med 2012; 18: 1786-96.

30. Higashijima Y, Tanaka T, Yamaguchi J, Tanaka S, Nangaku M. Anti-inflammatory role of dpp-4 inhibitors in a nondiabetic model of glomerular injury. Am J Physiol Ren Physiol 2015; 308: F878-87.

31. Ferrannini E, DeFronzo RA. Impact of glucose-lowering drugs on cardiovascular disease in type 2 diabetes. Eur Heart J 2015; 36: $2288-96$

32. Marguet D, Baggio L, Kobayashi T, et al. Enhanced insulin secretion and improved glucose tolerance in mice lacking CD26. Proc Natl Acad Sci U S A 2000; 97: 6874-9.

33. Kawase H, Bando YK, Nishimura K, Aoyama M, Monji A, Murohara T. A dipeptidyl peptidase-4 inhibitor ameliorates hypertensive cardiac remodeling via angiotensin-II/sodium-proton pump exchanger-1 axis. J Mol Cell Cardiol 2016; 98: 37-47.

34. Ghorpade DS, Ozcan L, Zheng Z, et al. Hepatocyte-secreted dpp4 in obesity promotes adipose inflammation and insulin resistance. Nature 2018; 555: 673-7.

35. Ikedo T, Minami M, Kataoka H, et al. Dipeptidyl peptidase-4 inhibitor anagliptin prevents intracranial aneurysm growth by suppressing macrophage infiltration and activation. J Am Heart Assoc 2017; 6.

36. Mita T, Katakami N, Shiraiwa T, et al. Dose-dependent effect of sitagliptin on carotid atherosclerosis in patients with type 2 diabetes mellitus receiving insulin treatment: A post hoc analysis. Diabetes Ther 2017; 8: 1135-46.

37. Anderluh M, Kocic G, Tomovic K, Kocic R, Deljanin-Ilic M, Smelcerovic A. Cross-talk between the dipeptidyl peptidase-4 and stromal cell-derived factor-1 in stem cell homing and myocardial repair: Potential impact of dipeptidyl peptidase- 4 inhibi- tors. Pharmacol Ther 2016; 167: 100-7.

38. Yang G, Li Y, Cui L, et al. Increased plasma dipeptidyl peptidase-4 activities in patients with coronary artery disease. PLOS ONE 2016; 11: e0163027.

39. Yang G, Lei Y, Inoue A, et al. Exenatide mitigated diet-induced vascular aging and atherosclerotic plaque growth in apoedeficient mice under chronic stress. Atherosclerosis 2017; 264: $1-10$.

40. Sorci-Thomas MG, Thomas MJ. Microdomains, inflammation, and atherosclerosis. Circ Res 2016; 118: 679-91.

41. Lozhkin A, Vendrov AE, Pan H, Wickline SA, Madamanchi NR, Runge MS. Nadph oxidase 4 regulates vascular inflammation in aging and atherosclerosis. J Mol Cell Cardiol 2017; 102: 10-21.

42. Lim S, Quon MJ, Koh KK. Modulation of adiponectin as a potential therapeutic strategy. Atherosclerosis 2014; 233: 721-8.

43. Wu H, Du Q, Dai Q, Ge J, Cheng X. Cysteine protease cathepsins in atherosclerotic cardiovascular diseases. J Atheroscler Thromb 2018; 25: 111-23.

44. Wu H, Cheng XW, Hu L, et al. Cathepsin S activity controls injury-related vascular repair in mice via the tlr2-mediated p38 MAPK and pi3k-akt/p-hdac6 signaling pathway. Arterioscler Thromb Vasc Biol 2016; 36: 1549-57.

45. Moon JY, Woo JS, Seo JW, et al. The dose-dependent organspecific effects of a dipeptidyl peptidase-4 inhibitor on cardiovascular complications in a model of type 2 diabetes. PLOS ONE 2016; 11: e0150745.

46. Scirica BM, Bhatt DL, Braunwald E, et al. Saxagliptin and cardiovascular outcomes in patients with type 2 diabetes mellitus. N Engl J Med 2013; 369: 1317-26.

47. White WB, Cannon CP, Heller SR, et al. Alogliptin after acute coronary syndrome in patients with type 2 diabetes. $\mathrm{N}$ Engl J Med 2013; 369: 1327-35.

48. Filion KB, Azoulay L, Platt RW, et al. A multicenter observational study of incretin-based drugs and heart failure. N Engl J Med 2016; 374: 1145-54.

49. Green JB, Bethel MA, Armstrong PW, et al. Effect of sitagliptin on cardiovascular outcomes in type 2 diabetes. N Engl J Med 2015; 373: 232-42.

50. Holman RR, Bethel MA, George J, et al. Rationale and design of the exenatide study of cardiovascular event lowering (exscel) trial. Am Heart J 2016; 174: 103-10. 